\title{
Elaboration on Grammatical Errors of Descriptive Text by EFL Learners
}

\author{
Ari Prasetyaningrum ${ }^{1 *}$ and Maman Asrobi $^{2}$
}

\author{
${ }^{12}$ Universitas Hamzanwadi, Selong, Indonesia, \\ *Corresponding author. Email: rheafanny1981@gmail.com
}

\begin{abstract}
The research was conducted to know and to sort the kinds of grammatical errors in text made by the participants in descriptive genre. The error classifications followed the concept of Corder. Designed as qualitative study, the study took the second term learners of study program in English education at Hamzanwadi University which consisted 35 as the participants. Data was obtained from subjective examination in the form of descriptive text. The data analysis result described that learners' errors were divided into four categories: omission, addition, selection, and ordering. From the persistent of every error kinds, selection turned out to be the most often made by the participants $(57.9 \%)$. Furthermore, $30.30 \%$ errors were found as omission and $12.9 \%$ errors were grouped into addition; while, misordering just cover $17.4 \%$.
\end{abstract}

Keywords: Error analysis, descriptive text

\section{INTRODUCTION}

According to (Dimbleby \& Burton, 2020) writing is more than an author's effort in written medium. That means technique of creativity as well as a solution of producing ideas. Writing plays prominent roles as media in aural context to share thoughts, insights and to spread news. (Goodman, 2014) states that" writing is to produce a written word which finally results a text, but the text has to be readable and acceptable to create a communication. The students express their thoughts in the form of a passage from which familiar and unfamiliar readers will take out the interpretation in time". Writing immortalizes words permanently, and so enlarge the entire mind of a person from tiny cache that he may recall and transfer orally to the boundless size of a sophisticated library. On the contrary, EFL learners believe that writing become the most troublesome skill among speaking, listening and reading (Huy, 2015). (Hyland, 2019) strengthens the previous theory by providing a statement that writing is the most problematic skill to master by a lot of foreign language pupils. When the students are about to write, they often lack ideas about the series of story they wish to describe. The learners are not too assured whether their text is acceptable or not and organize the ideas into a passage is quite complicated (McCarthy, 2020)

To produce well-organized passage, learners are recommended to be skillful in some element of writing. (Biber \& Conrad, 2019) divides the elements of writing into five. They are the genre, register, discourse, grammar, and graphic features. (Qomar \& Erlina, 2017) says that "grammar means organized way to calculate and measure a speaker's knowledge about the language". It is examined by certain postulates that can be used to design the entire well organized syntax of a language. Furthermore, (Hodge \& Johnston, 2014) states that 'grammar refers to a study on what formations (or arrangement) are tolerate in a language. Grammar is one of the aspects that has vital effect in writing, but the barrier is, a number of learners produce some errors when they produce a sentence and organize some sentences into a paragraph (Alfaki, 2015). It is a fact that English grammar pattern is totally unsimilar from that of Bahasa Indonesian. Yet, learners are often neglect their errors and incapable to correct the errors (Singh et al., 2017). Hence, the learners find it problematic to make progress in their writing skill. The grammar dissimilarity of the native language and English is one of the reasons, that causes the learners produce a large number of grammatical errors which affect the subject matter of the text, then their meaning are not received completely to the readers (Sermsook et al., 2017).

(Amara, 2015) says that error is a structured disparity that the students write by learners who do not understand the regulations of the foreign language. A lot of learners' grammatical errors are identified during their learning process, especially in writing. Norrish (as cited in Nazir et al., 2018) divides the error reasons into three categories, they are inattention, first language effect, and translation. Error analysis refers to a step to find out and examine learners' instructional activity to 
classify the errors which are found in the text written by learners (Phuket \& Othman, 2015). During teaching and learning activity, learners sometimes produce certain errors. (Budiharto, 2019) states that errors which the learners created due to the fact that they are inhibited by the native language then they apply the orders in the foreign language. Moreover,(Al-Khasawneh, 2014) gives his definition about error analysis that is a procedure to find out, notice, and categorize the digression of the sentence pattern of a target language, then to discover the technique known by the students. According to (Munawaroh, 2018) who conducted a research to study the errors produced by learners is one strategy to reveal the real ability of a foreign language they are studying in a certain time.

Based on the explanation previously, the research purpose was to classify the most frequent errors which are found in descriptive paragraph made by learners . descriptive paragraph is defined as a genre which describes both a person and object's appearance. While, description refers to the component belongs to paragraph which narrate certain figures or it could be defined that a descriptive text refers to a genre which tells the the characteristics of an individual, an object, or a certain spot (Husna, 2017). The most important language features in descriptive text is simple present. simple present tense is always applied for scientific facts and daily routine as well (Mogashoa, 2014). It is one of text genres that is introduced at the first year exactly since the second semester apart from narrative, recount, descriptive and procedure. As stated previously, the primary language feature of descriptive text is simple present tense. Simple present tense is used for events which become the natural fact and habitual actions as well. The most dominant difficulties observed in descriptive paragraph is the learners fail to arrange the generics structures in order and language features (Setyawan \& Rochsantiningsih, 2014). They depict and explain the object or a character that they want to describe directly, yet the most urgent point lies in grammar, and there are various errors emerge in the learners' writing result. It is why the learners are distracted to arrange correct grammar and make errors though they have learned English for long time and learnt grammar from high school. As it is stated previously the background of study, the author has to answer the question of problem as follows; what types of the most dominant grammatical errors which the learners wrote in descriptive text?

The author classifies the errors based on Corder's theory. Corder et al in (Mardalena, 2017)) points out there are four types of errors related to grammatical categories, there are error of omission, error of addition, error of selection and error of misordering points out there are four types of errors related to grammatical categories, namely error of omission, addition, selection and misordering. Hence, According to (Abushihab, 2014) error analysis is a part of Applied Linguistic which contain particular purposes. The first purpose tends to theoretical which can be found in method and explain the learners' recognition of the foreign language. The second purpose is to enable the researcher to find out the relation between the knowledge and teaching the learner has been receiving. Thus, analysis of grammatical error plays a role to examine the error types which the learners usually create. Eventually, the author was inspired to carry on a study on error analysis for the second semester of English education study program students at Hamzanwadi university which identified Grammatical Errors of Descriptive text for the second tem leaners at Hamzanwadi University in academic year 2020-2021

\section{METHOD}

Qualitative approach was applied in this study. (Kahlke, 2014) states, qualitative study is defined as a perspective to analyze social events and had a naturalistic and interpretative type, and require numerous systems of examination. (Ormston et al., 2014) states qualitative approach tend to realistic analytical deal with the meaning knowledge that a person connect to a happening (activity, commitment, trust, norms, etc) around one's social association. (Castleberry \& Nolen, 2018) state that qualitative research is done descriptively which mean data collection technique is in the form of sentences or portraits instead of numeral. The writer showed the data in words in spite of quantitative statistics. As an addition, this study was made in a case study and the author analyzed one subject only. According to (Duff, 2014), a case study means a thorough research deals with a participant, a number of society or an entity which the researcher analyzes detail data dealing with different variables ".The examination was held twice to find out whether the learners made mistakes or errors Furthermore, the data collected were examined to choose the kinds of errors based on the theory by Corder. In the research, errors were divided into five types: error of ordering, selection, omission and finally addition. The illustration on error classification are shown in atable proposed by James. Finally, to understand the frequent of every error kind, the author applied descriptive analysis which later was calculated into percentage.

\section{RESULTS \& DISCUSSION}

After collecting the data, the author examined the grammatical error and sorted the type on the basis of 
the Surface Categories to find out to what categories these errors belong to whether omission, addition, selection, or ordering. Then the data finding was described in theTable 1 as follow:

Table 1. The calculationof Error class, recurrence and Percentage

\begin{tabular}{|c|c|c|c|c|c|c|}
\hline \multirow[t]{2}{*}{ No } & \multirow[t]{2}{*}{ Level/modification } & \multirow[t]{2}{*}{ Substance } & \multicolumn{2}{|l|}{ Text } & \multirow[t]{2}{*}{ discourse } & \multirow[t]{2}{*}{ Total of error } \\
\hline & & & Grammar & Lexis & & \\
\hline 1 & Omission & & $47(30.3 \%)$ & & & $47(30.3 \%)$ \\
\hline 2 & Addition & & $20(12.9 \%)$ & & & $20(12.9 \%)$ \\
\hline 3 & Selection & $9(5.8 \%)$ & $30(19.5 \%)$ & $4(2.5 \%)$ & $18(11.6 \%)$ & $61(39.3 \%)$ \\
\hline 4 & Ordering & $4(2.8 \%)$ & & & $13(8.3 \%)$ & $27(17.4 \%)$ \\
\hline \multicolumn{2}{|c|}{ TOTAL } & $155(100 \%)$ & & & & \\
\hline
\end{tabular}

Having analyzed the data of the table, a conclusion was drawn that the total number of omission errors was 47 errors $(30.3 \%)$. the addition are 47 errors $(12.9 \%)$ in the part of grammar text. The selection errors found were $61(39.3 \%)$. Errors in substance level are 9 errors $(5.8 \%)$, in grammar text level are 30 errors $(19.5 \%)$, in lexis level are 4 errors $(2.5 \%)$ and in discourse level is 18 errors $(11.6 \%)$. While the error of ordering is 27 errors $(17.4 \%), 4$ errors $(2.8 \%)$ in substance level, and in discourse level 13 errors $(8.3 \%)$. From the total data recapitulation, selection error is the most persistent error found in descriptive text by the second term learners of English study program at University of Hamzanwadi with the result of $39.3 \%$ followed by error of omission with $30.3 \%$, next ordering and addition errors with percentage lower than $30 \%$.

Omission error emerged at the time the learners omit a word compulsory aspect. Error in omission were found not only in the core sentence but also in the grammar of the sentence. A lot of learners make errors by removing a letter that ought to present in particular morpheme.for example "she have mole on the face". While she is supposed to write she has a mole on her face $*$ she smarter than me. yet she is expected to arrange such right sentence as "she is smarter than me".

Having observed the previous example, it is known that the article and verb usage were neglected by the learners. The logic why this kind of error happen is they do not find the existence the article and verb in the whole Indonesian text. The error derives from interlingualtransfer. Students were unable to apply the basic sentence order of English well.

In error of "addition". It occured for the participants did not master sentence structure and grammar. Thus, the reason of this type of error derives from the transfer of interlingual. The learners put down nonessential word which are unnecessary to the sentence. As an example, "his siblings is Andi brother and Niena sister". Two words of brother and sister have to be omitted since those are unnecessary. It was known that although the words 'dad' and 'mom' are removed, the readers understood that Andi is her brother and Niena is his sister. Thus, the correct response is expected to be "her siblings are Andi and Niena". A different pattern is *her physics short". Whereas, the learner are expected to make "his height", the word physics is unnecessary in that sentence structure.

Related to the selection error, the author identified that there are 61 errors or $39.3 \%$ ( the substance level error were 11 or $8.6 \%$ in grammar level were 30 or 19.5 $\%$, in lexis level were 4 or $2.5 \%$, and in discourse level was 38 covered $22.2 \%$ ) of all grammatical errors. Thus, this was the most frequent error which the learners made. Those errors emerged due to the fact that the learners understood insufficient stock of vocabulary and the diction as well. The learners were distract to pick up the proper word category.In this case,the example :I love Adipati Dolken because he is have skill.while the correct sentence is expected to be I admire Adipati Dolken because he is multitalented. From this example, it could be understood that the learner failed to pick right vocabulary so they misselect the words.

The ordering error which the author identified was 8 items or $4.7 \%$ in substance were 2 items or $1.2 \%$ and in discourse there were 31 items or $19.9 \%$. Sometimes ordering error occurs as the consequence from interligual transfer. The students were exposed by the grammar or the basic patterns of the native tongue namely Bahasa Indonesia. In the example I like song Justin Bieber". The right version should be 'I like Justin Bieber's song.

In this part, the author categorized the errors in accordance with their error source which meant to examine the error on the basis of dissimilarity between Indonesian and English language structure as the target language with distinctive language rules (intralingual). Thus the author did not take the error factors on instructional and social setting.

An interlingual transfer is defined as the error which occurs when learners still apply their mother tongue sentence structure which in consequence they just 
translate Bahasa Indonesia to English straightly. It is a fact that Indonesian as well as English do not follow similar sentence rules. As an example, ${ }^{*}$ I have someone idol her name Prilly Latuconsina' the right one should be I have an idol her name is Prilly Latuconsina. the next example such as: I have a idol, he smart cooking,the accurate sentence is I have an idol, he is good at cooking. ${ }^{*}$ I like him because good looking and gentle and he is a master chef 2015 runner up. Whereas, he is expected to make I admire him because he is charming and he is a runner up of master chef 2015. The errors occurred since the rules of Indonesian language which is the native language and English do not share similarities. The learners omitted two verbs, -is, -ing, misselected and removed "a" as the article. When the author checked to the interview result, the learners did not comprehend the grammatical rules well and they did not conceive of the sentence basic pattern because the teacher did not teach them comprehensively. Therefore, the cause comes from interlingual transfer since the learners were still affected by their native language.

Errors in intralingual transfer appeared since the learners made excessively vague on the sentence structures in inaccurate notions. Hence intralingual transfer occurred due to incomplete teaching. As an example, *she is was born in Selong. In the previous sentence, the student understood where to place the verb which succeeded subject, yet she did not aware the right pattern. Thus, she wrote both linking verb -is and -was respectively. However, she was expected to write "she was born in Selong." The factor of this type of error is intraingual transfer since they overproduced pattern which in erroneous ideas.

If the purpose of analysis on grammatical error is to ease learners to learn foreign language, it is recommended that the grammatical errors be revised. Same errors may be assumed more significant than the others due to the fact that they may distract the sense of the meaning. In this study, the author assumed that errors which appeared due to incomplete understanding tend to cause an effect to the learners say for example they do not have comprehensive insight or misunderstanding toward certain lesson.

The research findings of grammatical error analysis indicated that learners produced four kind of errors: omission, addition, selection, and ordering . From the abundance of every error class, selection belong to the error which most persistent found in the students' descriptive text which covered $57.9 \%$ of the entire errors. Furthermore, $30.30 \%$ errors was classified into omission next $12.9 \%$ errors was categorized into addition; while, misordering errors were just $17.4 \%$. The mentioned errors were identified due to the fact that a large number of pupils fail to recognize the structure sentence of English well, that they subtract the rules and utilize it partly. Besides, the errors occurred as their mother tongue and English sentence pattern interfere. To summarize, it was proved that the grammar application in descriptive text is quite problematic for learners. The reasons were the learners were still had insufficient knowledge of the English grammar especially about tenses since in Bahasa Indonesia does not share similar tense system, so the time and the event are different from English. As a consequence, they often commit grammatical errors in texts.

The most persistent errors found in by the participants' writing product was in selection error. As Brown states, the first step of a language is identified by prevalence of intralingual transfer, yet when students start to gain portion of the latest technique, interlingual generalization on the target language will increase, then earlier chances start to grasp system belong to the foreign language.

In this case, the learners often commit selection errors when they pick the inaccurate word in the correct position. For example; she have mole on her cheek while it is supposed to be she has mole on her cheek.

\section{CONCLUSIONS}

Having elaborated the description previously, this study goal was to identify and categorize the kinds of grammatical errors learners create in descriptive text genre The errors found were sorted based on the theory of Corder. The author draw a conclusion that the types of error committed by the second term learners in English education study Program of Hamzanwadi University in their descriptive text from the commonest to the least among others were error of selection, omission, addition, and ordering. The finding of the elaboration in grammatical error proved that learners' errors were divided into four types: omission, addition, selection and ordering. Based on the persistence of every error class, selection belong to the most often made by the learners which covered $39.3 \%$ of the whole errors. Furthermore, $30.30 \%$ errors were categorized into omission and $12.9 \%$ errors belong into addition: while, misordering error was only $17.4 \%$.

It is indicated that the implementation of grammatical pattern in English text is problematic for the learners. Therefore, grammatical error study in writing is significant due to the fact that lecturers realize the real proficiency of the learners in writing skill and kinds of error which the learners may make in their text another chance. Based on the theory, errors are tolerable in education context since it is a step of grasping knowledge. Therefore, certain errors appeared at the time the author did the study. The present study identified that the error frequency that a large number of 
students did was found in selection error, that was 61 errors or $39.3 \%$. It has covered errors in substance pattern that was 13 items or $8.6 \%$, in grammar rules was 30 items or $19.5 \%$, in lexis text part was 4 items or $2.5 \%$, and in discourse level was 31 items or $19.9 \%$.

\section{REFERENCES}

[1] Abushihab, I. (2014). An analysis of grammatical errors in writing made by Turkish learners of English as a foreign language. International Journal of Linguistics, 6(4), 213.

[2] Al-Khasawneh, F. M. (2014). Error analysis of written English paragraphs by Jordanian undergraduate students: A case study. International Journal of English Language, Literature and Humanities, 2(4), 85-100.

[3] Alfaki, I. M. (2015). University Students'english Writing Problems: Diagnosis And Remedy.

[4] Amara, N. (2015). Errors correction in foreign language teaching. The Online Journal of New Horizons in Education, 5(3), 58-68.

[5] Biber, D., \& Conrad, S. (2019). Register, genre, and style. Cambridge University Press.

[6] Budiharto, R. A. (2019). Native language interference on target language writings of Indonesian EFL students: An exploratory case study. Indonesian EFL Journal, 5(1), 107-116.

[7] Castleberry, A., \& Nolen, A. (2018). Thematic analysis of qualitative research data: Is it as easy as it sounds? Currents in Pharmacy Teaching and Learning, 10(6), 807-815.

[8] Dimbleby, R., \& Burton, G. (2020). More than words: An introduction to communication. Routledge.

[9] Duff, P. A. (2014). Case study research on language learning and use. Annual Review of Applied Linguistics, 34, 233.

[10] Goodman, K. S. (2014). Reading, writing, and written texts: A transactional sociopsycholinguistic view. In Making Sense of Learners Making Sense of Written Language (pp. 55-67). Routledge.

[11] Hodge, G., \& Johnston, T. (2014). Points, depictions, gestures and enactment: Partly lexical and non-lexical signs as core elements of single clause-like units in Auslan (Australian sign language). Australian Journal of Linguistics, 34(2), 262-291.

[12] Husna, L. (2017). An analysis of students' writing skill in descriptive text at grade X1 IPA 1 of MAN 2 Padang. Jurnal Ilmiah Pendidikan Scholastic, 1(1), 16-28.

[13] Huy, N. T. (2015). Problems affecting learning writing skill of grade 11 at Thong Linh high school. Asian Journal of Educational Research,
$3(2)$.

[14]Hyland, K. (2019). Second language writing. Cambridge university press.

[15] Kahlke, R. M. (2014). Generic qualitative approaches: Pitfalls and benefits of methodological mixology. International Journal of Qualitative Methods, 13(1), 37-52.

[16] Mardalena, D. (2017). An Error Analysis on the Use Of Action Verbs On Recount Writing Made By The Eleventh Grade Students Of Sma Nurul Amal Palembang In Academic Year 2016/2017.[Skripsi]. Uin Raden Fatah Palembang.

[17] McCarthy, L. P. (2020). A stranger in strange lands: A college student writing across the curriculum. Routledge.

[18] Mogashoa, T. (2014). Understanding critical discourse analysis in qualitative research. International Journal of Humanities Social Sciences and Education, 1(7), 104-113.

[19] Munawaroh, S. (2018). An Analysis of Students'grammatical Errors In Using Simple Present Tense In Writing Descriptive Text At The First Semester Of The Eleventh Grade Of Sma Negeri 1 Mesuji Timur In 2017/2018 Academic Year. UIN Raden Intan Lampung.

[20] Nazir, I., Syamaun, A., \& Erdiana, N. (2018). An Analysis of Grammatical Errors Made by Students in Writing Descriptive Text. Research in English and Education Journal, 3(4), 220-230.

[21] Ormston, R., Spencer, L., Barnard, M., \& Snape, D. (2014). The foundations of qualitative research. Qualitative Research Practice: A Guide for Social Science Students and Researchers, 2, 52-55.

[22] Phuket, P. R. N., \& Othman, N. B. (2015). Understanding EFL Students' Errors in Writing. Journal of Education and Practice, 6(32), 99-106.

[23] Qomar, A. H., \& Erlina, I. A. H. (2017). Developing Material For Communicative Language Teaching (Clt) To Teach English For Economics Students. Premise: Journal of English Education and Applied Linguistics, 6(2), 12-19.

[24] Sermsook, K., Liamnimit, J., \& Pochakorn, R. (2017). An Analysis of Errors in Written English Sentences: A Case Study of Thai EFL Students. English Language Teaching, 10(3), 101-110.

[25] Setyawan, G. Y., \& Rochsantiningsih, D. (2014). Optimizing Google Docs To Improve Students'writing Skill of Descriptive Text. English Education, 2(2).

[26] Singh, C. K. S., Singh, A. K. J., Razak, N. Q. A., \& Ravinthar, T. (2017). Grammar Errors Made by ESL Tertiary Students in Writing. English Language Teaching, 10(5), 16-27. 